\title{
Quantification of cellulolytic bacteria using in vitro culture containing treated or untreated cottonseed hulls determined by real-time polymerase chain reaction
}

A Faramarzi Garmroodi, M Danesh Mesgaran, A R Vakili, A R Heravi Moussavi, A Tahmasbi, H Jahani-Azizabadi

Department of Animal Science, Excellence Center for Animal Science, Ferdowsi University of Mashhad, Mashhad, Islamic Republic of Iran

Email: ali_faramarzi_g@yahoo.com

Introduction Treatment of lignocellulosic substances with an alkali solution removes lignin and decreases the crystallinity of cellulose, thereby increasing the biodegradation of cell walls by fibrolytic micro organisms located in the rumen (Gould, 1984; Krause, 2003). Major fibrolytic bacteria are the gram-negative Fibrobacter succinogenes, and two species of grampositive bacteria, Ruminococcus albus and Ruminococcus flavefaciens (Krause, 2003). The objective of the present experiment was to quantify the cellulolytic bacteria population using in vitro culture containing sodium hydroxide treated or untreated cottonseed hulls $(\mathrm{CH})$ determined by real-time polymerase chain reaction (RT-PCR).

Material and methods Cottonseed hulls were used as untreated or treated with $\mathrm{NaOH}$ as $20 \mathrm{~g} / \mathrm{kg} \mathrm{DM}$ [a $20 \%$ solution of $\mathrm{NaOH}$ was sprayed on $\mathrm{CH}$ and kept for $48 \mathrm{~h}(\mathrm{CH} 2 \mathrm{~S} 48)$ at room temperature]. Samples were incubated in medium prepared as described by Arroquy et. al. (2005). Forty-five $\mathrm{ml}$ of medium was supplied into a $100 \mathrm{ml}$ bottle containing $0.45 \mathrm{~g}$ of the feed sample ( 3 replicates). Then, each bottle was inoculated under carbon dioxide with $5 \mathrm{ml}$ of isolated rumen bacteria. Rumen fluid was obtained from three sheep $(49.5 \pm 2.5 \mathrm{~kg}$ body weight) fitted by rumen fistulae, before the morning feeding. The animals fed $1 \mathrm{~kg} / \mathrm{d}$ DM of lucerne hay and $0.3 \mathrm{~kg} / \mathrm{d}$ DM of concentrate $(165 \mathrm{~g} \mathrm{CP} / \mathrm{kg} \mathrm{DM})$. Rumen fluid was immediately strained through four layers of cheesecloth. Then, the rumen fluid was centrifuged (10 min, $3000 \mathrm{rpm})$ and a solution of cycloheximide was added to protozoa free supernatant. The bottles were incubated for $96 \mathrm{~h}$ at $38.6^{\circ} \mathrm{C}$. After the incubation, $1 \mathrm{ml}$ of each bottle was sampled for DNA extraction. The extraction was done using Bioneer Accuprep Genomic DNA Extraction Kit. The 16s rRNA gene-targeted primers sets used in the present study were forward: 5'GTGSTGCAYGGYTGTCGTCA-3', 5'-GTTCGGAATTACTGGGCGTAAA- 5', 5'CCCTAAAAGCAGTCTTAAGTTCG- 3' and 5'-CGAACGGAGATAATTTGAGTTTACTTAGG- 3' for total bacteria, Fibrobacter succinigenes, Ruminococcus albus and Ruminococcus flavefaciens, respectively, and reverse: 5'ACGTCRTCCMCACCTTCCTC- 3', 5'-CGCCTGCCCCTGAACTATC- 3', 5'-CCTCCTTGCGGTTAGAACA- 3', 5'CGGTCTCTGTATGTTATGAGGTATTACC- 3' for total bacteria, Fibrobacter succinogenes, Ruminococcus albus and Ruminococcus flavefaciens, respectively. Then, quantification of cellulolytic bacteria was carried out using RT-PCR (2 replicates for each primer). Bacterial $\mathrm{rDNA}$ concentrations were measured relative to total bacteria amplification $(\Delta \Delta \mathrm{Ct})$. Data were analyzed using the GLM procedure of SAS 9.1 and the means were compared by the Tukey test $(\mathrm{P}<0.05)$.

Results Quantity of the major species of cellulolytic bacteria existing in the in vitro culture relative to total bacteria population is shown in Table 1. Chemical treatment had no significant effect on the quantity of cellulolytic bacteria under present experimental condition.

Table 1 Quantity of the major species of cellulolytic bacteria existing in the in vitro culture relative to total bacteria population

\begin{tabular}{llll}
\hline \hline & Bacteria & & \\
\hline Items & $\begin{array}{l}\text { Fibrobacter succinogenes } \\
\times\left(10^{-4}\right)\end{array}$ & $\begin{array}{l}\text { Ruminococcus flavefaciens } \\
\times\left(10^{-7}\right)\end{array}$ & $\begin{array}{l}\text { Ruminococcus albus } \\
\times\left(10^{-4}\right)\end{array}$ \\
\hline Untreated CH & 12 & 950 & 17 \\
$\mathrm{NaOH}$-treated CH & 13 & 560 & 14 \\
s.e.m & 0.002 & 0.003 & 0.004 \\
$\mathrm{P}$ & $>0.05$ & $>0.05$ & $>0.05$ \\
\hline \hline
\end{tabular}

Conclusions Results of the present study indicate that the in vitro relative quantity of the major species of cellulolytic bacteria was not influenced by sodium hydroxide treatment of $\mathrm{CH}$. Therefore, it was concluded that the treatment of $\mathrm{CH}$ with $\mathrm{NaOH}$ solution, as done in the present study might not alter the fibrolytic bacteria population. It was previously indicated that the digestibility of fibrous materials is generally related to rumen bacterial populations which are capable of producing wide range of fibrolytic enzymes (Krause, 2003). Therefore, it is not reasonable to get significant difference in digestibility of fibrous materials when treated with $\mathrm{NaOH}$ as obtained by Petersen et al. (1981), who reported no significant differences in $\mathrm{OM}$ digestibility of the roughages treated with $\mathrm{NaOH}$ at $4 \%$ of DM.

\section{References}

Arroquy, J. I., Cochran, R. C., Nagaraja, T. G., Titgemeyer, E. C., and Johnson, D. E. 2005. Animal Feed Science and Technology. 120, 93-106.

Gould, J. M. 1984. Biotechnology and Bioengineering. 26, 46.

Krause, D. O., Denman, S. E., Mackie, R. I., Morrison, M., Rae, A. L., Attwood, G. T., and Mcsweeney, C. S. 2003. FEMS Microbial Review. 27, 663-693.

Petersen, M. K., Thomas, V. M., and Roffler, R. E. 1981. Journal of Animal Science. 52, 398-405. 